\title{
A Study of Parsi Diaspora in Rohinton Mistry's Family Matters
}

\author{
R. Sellaraj Manuneethi
}

Assistant Professor of English

Pope's College

Sawyerpuram, Tamil Nadu, India

rsmanuneethi@yahoo.com

\section{Abstract}

Rohinton Mistry is one of the award winning Indian Writers. He is now living in Toronto. His famous novels are: "Such a long Journey", "A Fine Balance" and "Family Matters". Being a Parsi writer, he probes deep the problems of Parsi community in his novels.

The present paper focuses on one of his novels "Family Mattters" It is a typical Parsi novel. Like other Parsi writers, Mistry's work is guided by this experience of double displacement. As a Parsi, Mistry finds himself at the margins of Indian society and hence his writing challenges and resists absorption by the dominating and Hindu glorifying culture of India

This novel is Rohinton Mistry's hard to be suppressed presently to return home and reintegrate into the Pari community in India. Bombay to be specific. He exposes the general Parsi features through all the main characters of this novel. To be specific, the protagonist Nariman Vakeel is presented as an embodiment of Parsi community 
Born and raised in Bombay, where the majority of the Parsi community live, Rohinton Mistry is a critically acclaimed, award winning, and internationally famous author. He now lives in Toronto where he moved to in the early 1970s and he uses his pen to explore and highlight the eccentricities, the culture, the heritage, and the legacy of his own race.

The Parsi's are a small yet united, religious community in India, devoted to Zorostrainsism whose ancestors fled Islamic persecution in Iran (ancient Persia) during the eighth century. Today about, $1,50,000$ people follow the faith originally propagated by the prophet Zoraster. The largest Parsi community is now in Bombay.

During India's colonial period, the Parsi were particular favourities of British rulers. Both parties cooperated well together and this entente has often been dubbed 'the psychological diaspora' of the Parsi found themselves toeing 'the line of discontent' between two warring regions. This situation provoked many departures to England and America; making western diaspora of the Parsi.

Like other Parsi writers, Mistry's work is guided by this experience of double displacement. As a Parsi, Mistry finds himself at the margins of Indian society and hence his writing challenges and resists absorption by the dominating and Hindu glorifying culture of India. Here I would like to quote Narendrakumar:

The Parsi prefer the West since it offers unlimited scope for Parsi's growth and prosperity. Dislocation is part of the Parsi's Psyche. Exiled twelve hundred years ago, they came to India. Now they are migrating to West in search of greener pastures. Then there is 'double migration' in the case of Parsi's.

Mistry has so far published four novels such as "Such a Long Journey", "A Fine Balance", "Family Matters" and "The Scream". The novel for our present study is "Family Matters”. It is a typical Parsi novel. Mistry's backward glance at his native land reveals his diasporic consciousness tactfully. 
The novel is set in the city of Mumbai and tells the story of middle class Parsi family living through a domestic crisis. At the centre of the book is Narimn Vakeel, a retired English Professor, a Parsi with Parkinson disease. He has become bedridden after breaking his ankle in a fall. Nariman has bequeathed separate apartments to the two branches of his family. His step children, Jal and Coomy, occupy the larger portion in a building called Chateau Felicity. His daughter, Roxana and his son-in-law, Yezad and their two children Murad and Jehangir live in a smaller apartment in a block named Pleasant Villa. Nariman is living with Jal and Coomy in Chateau Felicity. Coomy is terribly put upon having to deal with her step father's excretions. She sent Nariman to Roxana's tiny flat. Roxana's family struggles with financial crisis. Coomy dies in a terrible accident that occurs when she is working on the ceilings in her flat. After Coomy's death, Jal calls Roxana's family and Nariman to stay with him in Chateau. The story ends with an epilogue that shows what happens after five years.

This novel is Rohinton Mistry's hard to be suppressed presently to return home and reintegrate into the Pari community in India. Bombay to be specific. He exposes the general Parsi features through all the main characters of this novel. To be specific, the protoganist Nariman Vakeel is presented as an embodiment of Parsi community.

Nariman's sense of isolation and his ailments that are essentially typical of the Pari community, the tragic death of his beloved Lucy and his wife, he neglect by the step children and his wife and his final resolution to seek shelter I Zorostrian and its rituals clearly indicate that "Family matters" is a typical Parsi Novel.

Nariman suffered mental agony in his young age, for his parents did not allow him to marry Lucy, a non-Parsi girl. Under compulsion he had to marry a Parsi widow. He could not forget his lady-love even in his old age. He, in fact, leads a miserable life until his death.

One can interpret Nariman's life as the rise and fall of Parsi community. Parsis came to India in fear of Arab invaders but in India, though they are treated well, they as a community 
are slowly because of late marriage, low birth rate, declining population etc. Nariman came to Pleasant Villa from Chateau Felicity to suffer a lot and finally dies. His death symbolically indicates the fall of Pari community.

Emigration is one of the themes of this novel. Parsis in India emigrate to foreign countries in search of money. Mistry, being an emigrant to Canada, vividly depicts Yezad's dream of emigrating to Canada. Thus, Mistry gives autobiographical touches to his portrayal of Yezad.

Expatriate Parsis are thrice removed; at first they fled from Iron to India, then from India to foreign countries and there they do feel attracted. That Mistry regrets his alienation as an emigrant, is expressed through Yezad's dream and musings. Yezad's wish for emigrating to Canada is symbolic of his quest for prosperity. It also indicates the thirst of Parsi community to achieve economic status with a view to ensuring security in life.

Yezad is eager to emigrate to Canada for he wants "Clean cities, Plenty of water, trains with seats for every one" (137). To Nariman, however, emigration is an 'enormous mistake'. In the end wisdom dawns on Yezad and he decides not to emigrate to Canada. He is so resolved that he destroys the letters, forms and photcopies related to his intended emigration. When he is tearing the papers Roxana comes in and asks what he is doing, he answers "getting rid of garbage".

Most of the Parsi writers use Mumbai as their locale. In fact, Mumbai is their home and their darling. The Parsis feel free and secure only when they are in Mumbai. The primary setting of "Family matters" is Mumbai. Mistry’s favorite site, Mumbai pulsates in all its variety and flavor in this novel. They city Mumbai, in a way, is the real protagonist of the novel.

Mr. Kapur and his family (Yezad's employer) and had to flee from Punjab in 1947 to Mumbai and were received by the city happily. He says thus to Yezad, we had to run and we 
came here. But Bombay treated us well. My father started over, with zero and became prosperous. Only in this city in the world where it is possible."(151)

Mistry praises Mumbai for giving shelter to each and every one.

The Parsi writers express their fears through their writings so as to caution their community about their falling population. In "Family Matters" Mistry expresses his apprehension about the downfall of the community. Inspector of Masalavala, Jal and Dr. Fitter discuss the future of the Parsi community. They agree that the factors contributing to the downfall are 'dwindling' birthrate and our men and women marrying non - Parsis and the heavy migration to the West”. (412)

Inspector Masalavala expresses his fear thus:

"The experts in demographics are confident that fifty years hence, there will be no Parsi left. “(412)

Parsis are apathetic to Indian politics in "Family Matters", Yezad, aware of the terror tactics of Shiv Sena, decides to send Goutham, and Bhaskar disguised as Shivsainiks to threaten his employer Kapur. The minor character Hussain expresses his anguish over Babri Masjid incident in which his wife and three sons were burnt to death. Mistry digs at the Shiv Sena and feels sorry for Mumbai for "it is being raped by politicians" (157). He calls Shiv Sena "the greatest urban manace (202).

Rohinton Mistry thus in his "Family Matters" has explored the relationships at the heart of his community, their cultural identity, and the uniqueness of their community living thereby showed the diasporic Parsi experience he has possessed. 


\section{Work Cited}

Narendra kumar V.L.V.N., Westernization and Expatriation, Parsi Novel, ed V.I.,V.N.

Narendrakumar, New Delhi Prestige books, 2002. 